\title{
A Financial Perspective on SMMEs Developmental Position During the Covid Pandemic
}

\author{
Sunitha Devi ${ }^{1,{ }^{*}}$ Putu Riesty Masdiantini ${ }^{1}$ Putu Eka Dianita Marvilianti Dewi ${ }^{1}$ A.A.N. \\ Yudha Martin Mahardika² Ida Bagus Raminra Padma Diputra ${ }^{1}$
}

\author{
${ }^{1}$ Department of Economic and Accounting, Universitas Pendidikan Ganesha, Singaraja, Indonesia \\ ${ }^{2}$ Department of Management, Universitas Pendidikan Ganesha, Singaraja, Indonesia \\ *Corresponding author. Email: sunitha.devi@undiksha.ac.id
}

\begin{abstract}
The COVID-19 pandemic certaintly has an impact on the economy, not only in Indonesia but also in the world. When the crisis hit in the 1997-1998 period, only SMMEs could strongly survive. The Minister of Finance, Sri Mulyani Indrawati observed this condition differently during the economic crisis during the current COVID-19 pandemic. The economic crisis due to the COVID-19 pandemic was felt as a tremendous pressure for SMMES actors because they could not hold business activities optimally as a result of community activities. Therefore, research related to the position of SMMEs development during the COVID-19 pandemic was important to be conducted in finding out the impact of this situation on the economic sector. The population of this study was 32,890 SMMEs with a sample of 110 SMMEs determined by the use of Slovin formula. The results showed that there were several differences viewed from many terms experienced by SMMES actors before and after facing the economic crisiss due to COVID-19 pandemic, such as; in terms of sales, income, and operating profit.
\end{abstract}

Keywords: Income, Operating Profit, SMMEs, Sales.

\section{INTRODUCTION}

The COVID-19 pandemic certainly has an impact on the economy sector, not only in Indonesia and even all over the world. One of the impacts found in Indonesia is the reduction in the tax revenue budget in which it is the largest source of state revenue, from 1,865.7 trillion to 1,462.6 trillion [1]. Tax revenue is the main source of state income which can be seen from the percentage of state revenue from tax revenues, for instance: by $84.4 \%$ or 1.332.06 trillion in 2019 [1]. The phenomenon of the reduction in the target of state revenue sourced from taxes in 2020 is a result of the existence tax incentives for taxpayers and business actors as stated and regulated in the Regulation of the Minister of Finance No. 44 PMK 03 of 2020 concerning on the Incentives Taxes for Taxpayers affected by the 2019 Corona Virus Disease Pandemic issued on 27 April 2020. The government has analyzed that in times of difficulty or crisis economy due to the COVID-19 pandemic will certainly have an impact on decreasing profits and declining the financial performance in various types of businesses, therefore the policy of the tax incentives application is the government's first step to economically rescue the most affected sectors, particularly the absorbing labor that is supposed repair the sector in order to survive in the midst of economic conditions due to the COVID-19 pandemic. The first tax incentives is aimed at the Micro, Small and Medium Enterprises (SMMES) sector.

Basically the economic crisis can have an impact on the decline in sales of products produced by companies [2]. Decrease in total sales that will have an impact on business development [3]. This is different from the phenomenon of the economic crisis situation due to the current COVID-19 pandemic. Based on a big data review related to the impact of the COVID-19 pandemic, it is stated that the policy of work from home during the COVID-19 pandemic resulted in the sale of cosmetics and household appliances which are included in the manufacturing sector, which is continued the increasement during the last 3 months, started from February to April 2020 [1]. Meanwhile, the 
Association's Head of Public Policy Indonesian Entrepreneur (Apindo), Sutrisno Iwantono states that the resilience of entrepreneurs SMMEs in Indonesia are different depending on the sector. However, in general they will only be strong in the sense of being able to finance the expenses without income, until it is finally closed. This is only strong for the next three months if corona not ends (CNBN, 2020). The difference impact of the state's financial difficulty situation in 2008 with 2020 on the level of sales or financial conditions in each SMMES industry sector lead to the importance of quantitative testing related to business developments in each SMMES sector during the COVID 19 pandemic, based on financial information obtained from SMEs.

According to [4] conducted research related to the company performance during the COVID-19 pandemic, but the research was limited to a phenomenological qualitative approach. The results showed that the hardest hit business sectors are those that rely on crowds such as restaurants in tourism places, entertainment service businesses, salons and the like. And there are many other sectors that are affected in various ways. The business sector that has the potential for having a benefit from social restrictions during the COVID-19 pandemic in which it is goods delivery service providers. Trading businesses that sell certain types of products such as; masks, providers of hand sanitizers, disinfectants, soaps, and similar products also have the potential to experience business development. The media sector (especially outside the print media) is another business that has the potential to have a profit from the increasing number of advertisers due to restrictions on physical movement. The food sector is considered as a stable business in the crisis period, that only experience adjustments in the methods, both ordering, payment and delivery methods.

The information provided based on the results of the research conducted by [4] in which qualitative data collection was conducted. The qualitative data was obtained from various interviews reported from various media with a focus on discussing economic losses due to the COVID-19 pandemic in Indonesia. According to [4] also describes the condition of the company's performance in general, therefore his research not specifically reviews the SMMES sector but also go public companies. On this basis, it is very important to conduct research to prove the results of reference [4] through quantitative testing. This research is conducted by examining the development of SMMES businesses during the COVID-19 pandemic through a quantitative approach to see the SMMES sectors that were negatively affected or even positively affected by the COVID-19 pandemic situation. The results of this research are expected to provide scientific information related to SMMES sectors that are able to survive in the current COVID-19 pandemic that can be used as a reference in focusing to strengthen the sector to help make the National Economic Recovery (PEN) program a success.

Based on the amount of BPUM revenue, Buleleng Regency SMMEs have the most opportunity and play an important role in helping economic growth in Bali through the survival in the midst of the COVID-19 pandemic situation, which reached 90, 53 bilion. Therefore, research related to the position of this SMMES development conducted in Buleleng Regency with the aim of reviewing the effectiveness of BPUM utilization in business development by SMMES actors in Buleleng Regency as the highest BPUM recipient. The concept of business development used in this study is viewed from a financial perspective by assessing the development of sales, revenues, and operating profits. In order to deepen the results of this study, qualitative testing is also carried out to determine the key factors that can encourage business development during the COVID 19 pandemic. This information will be explored through in-depth interviews with SMMES actors who have significant business increase values.

\section{LITERATURE REVIEW}

\subsection{Resource Based Theory}

The company's performance will be optimal if the company has a competitive advantage that is difficult to imitate and it is strongly attached to the company's characteristics behaviour as described in resource-based theory. This is also expressed in the research of [5] which states that to help defend the financial performance of mining companies in China from various risky economic situations, it is necessary to create new competitive advantages for long-term development. Competitive advantage is obtained by utilizing, managing and controlling owned resources such as organizational processes and company strategies in dealing with various conditions, including when facing economic crisis situations. Resources that also need to be managed properly include assets, knowledge of technology, and the ability of human resources to manage the company in various situations and conditions. The company's performance is very dependent on the ability of management to generate and manage unique and specific resources, so they are able to compete and survive in various situations.

\subsection{Definition and Types of SMMEs}

1) The criteria for micro enterprises are as follows:

a) Having a net worth of at most $\mathrm{Rp}$. $50,000,000$ (fifty million rupiah) excluding land and building for business premises; or 
b) Having annual sales of at most Rp. 300,000,000 (three hundred million rupiah).

2) The criteria for small businesses are as follows:

a) Having a net worth of more than Rp. $50,000,000$ (fifty million rupiah) up to a maximum of Rp. 500,000,000 (five hundred million rupiah) excluding land and buildings for business premises; or

b) Having annual sales of more than Rp. 300,000,000 (three hundred million rupiah) up to a maximum of $\mathrm{Rp}$. 2,500,000,000 (two billion five hundred million rupiah).

3) 3. The criteria for medium-sized enterprises are as follows:

a) Having a net worth of more than Rp. 500,000,000 (five hundred million rupiah) up to a maximum of Rp. $10,000,000,000$ (ten billion rupiah) excluding land and buildings for business premises; or

b) Having annual sales of more than Rp. 2,500,000,000 (two billion five hundred million rupiah) up to a maximum of $\mathrm{Rp}$. 50,000,000,000 (fifty billion rupiah).

\subsection{Business Development}

Development is a form of business for the business that can develop for the better and reach a point or peak towards success. Indicators of business development can be seen from the amount of revenue, profit, and sales value.

Income is income received by a person from a business or activity carried out within a certain period of time which can be in the form of goods and services. The definition of income according to IAI (Indonesian Accounting Association) in (PSAK No. 23, 2012: par 6) concerning Revenue Accounting in paragraph 6 states that income is a gross inflow of economic benefits arising from the entity's normal activities during a period if the inflow is resulting in an increase in equity, which is not derived from investment contributions. The amount of income can be used as an indicator of the success of a business. If the business income increases which is followed by an increase in profits and the number of customers, it can be said that the business is experiencing growth. In addition, the increase in labor indicates that customer demand for the goods sold is high, thus requiring additional labor to meet customer desires. Income itself is influenced by various factors. Research results reference [6]; [7] show that age, working hours, and working capital have a simultaneous and significant effect on income. The effect of age on income can be explained by the theory of production. Worker productivity is affected by age; The older the worker, the lower his work productivity. According to [8] explain that during the productive period, the workforce will have the potential to produce more products and services, which results in increased income. As you age, your productivity will decrease and your income will decrease. The decline in productivity in addition to lowering income, also reduces working hours. It should be underlined that although research results reference [7];[6] show that increasing working hours is often considered to increase income, work effectiveness is the key to increasing income. The amount of working time given by workers [9] and productivity during working time [10] determine the element of increasing income. In other words, simply adding working time without paying attention to work effectiveness and productivity does not have a positive effect on income. Another factor that is no less important than income is capital.

Capital is very useful for increasing production, and with the growth of production of products and services more and more and this has an impact on income [11]. Capital is the heart of business development [12], where the development and growth of a business cannot be separated from capital [13]. The three factors, age of labor, working hours, and capital if used properly will be able to increase income. If the business income increases which is followed by an increase in profits and the number of customers, it can be said that the business is experiencing growth. In addition, the increase in labor indicates that customer demand for the goods sold is high, thus requiring additional labor to meet customer desires.

According to [14], sales value is the total amount generated from the sale of goods. The greater the number of sales generated by the company, the greater the possibility of profit generated by the company in sales activities. The essence of sales value is applied in three appreciations, namely: first, the level of sales to be achieved, secondly the market that you want to develop as a transaction activity or a place to make transactions, and thirdly, profit on sales. The three essences basically provide a limit that sales value is defined as the addition of economic value generated through product offering activities from various industrial companies that offer purchases to consumers.

Profit is defined as the excess of income over costs during an accounting period [15]. Operating profit is the excess of income from operations over the (cost of goods soldcost of goods sold) plus operating expenses in a certain period [16] 


\section{METHOD}

Design used to answer the formulation of the research problem is a combination research design between quantitative and qualitative or often known as mixed methods. Mixed methods is adopting a research strategy that uses more than one type of research method with the aim of providing a broader understanding of research problems. Themodel mixed method chosen is sequential explanatory, which is a combination research method that combines quantitative and qualitative research methods sequentially, where in the first stage the research is carried out using quantitative methods and in the second stage qualitative methods are carried out [17].

Collection on a quantitative approach was carried out by distributing questionnaires to SMMES actors in Buleleng Regency. Apart from distributing questionnaires, the data to be analyzed quantitatively can also be obtained through secondary data.data secondary used in the study was in the form of financial statements Quartal period IV 2019 and the period of the second Quartal 2020 of SMEs registered in the Office of the District Bueleleng Dagperinkop SMEs. Data collection on a qualitative approach is carried out through interviews with SMMES actors who have been quantitatively proven to have increased their business from a financial perspective.

Population in this study are SMMEs registered with the SME Dagperinkop Service in Buleleng Regency in 2019 and remain registered until 2020. Based on this determination, a total population of 32,890 SMMEs is obtained which is divided into 14 sectors. The fourteen sectors include: 1) advertising, 2) architecture, 3) crafts, 4) design, 5) fashion, 6) video, film and photography, 7) interactive games, 8) performing arts, and 9) publishing and printing, 10) computer and software services, 11) television and radio, 12) research and development, 13) music, 14) culinary.
Determination of the number of samples is carried out using a statistical approach, namely using theformula Slovin to avoid the subjectivity of researchers in determining the number of samples. The error rate used is $5 \%$ with the confidence level of the sample to the population is $95 \%$. Analysis Datais quantitative research include descriptive statistics and analysis of different test relating to the development of SME business in Buleleng between before the economic crisis as a result of the pandemic COVID 19 with the current economic crisis as a result of the pandemic COVID 19. In the initial phase of testing will be conducted test normality of the data to determine the statistical test to be used in the difference test. Data normality test is an absolute requirement in parametric statistical tests, if the data are not normally distributed then the different tests that can be done are using nonparametricsuch as statisticsWilcoxon signed rank test. The data will be analyzed using SPSS version 25. Qualitative data analysis will be carried out using Nvivo.

\section{RESULTS \& DISCUSSION}

\subsection{Descriptive Analysis and Normality Test}

The results of the descriptive analysis in Table 1 show that there was a decrease in the average sales of Buleleng SMEs before the COVID-19 pandemic compared to sales during the COVID-19 pandemic. The average sales value before experiencing the COVID-19 pandemic was $190,666,666.7$ while the value for the average sales during the COVID-19 pandemic phase was $25,333,333.3$. The decrease in the average value of SMMES sales from before the COVID 19 pandemic phase to the COVID 19 pandemic situation was $165,333,333.4$. The decrease in average sales shows that the COVID-19 pandemic situation has had a negative impact on financial conditions seen from the sales value of SMMEs in Buleleng Regency.

Table 1. Descriptive Analysis Results

\begin{tabular}{|l|r|r|r|r|r|}
\hline & N & \multicolumn{1}{|c|}{ Min } & \multicolumn{1}{c|}{ Max } & \multicolumn{1}{c|}{ Mean } & Std. Deviation \\
\hline $\begin{array}{l}\text { Sales_Phase Before the COVID-19 } \\
\text { Pandemic }\end{array}$ & 110 & 10.000 .000 & 1.000 .000 .000 & $190.666 .666,7$ & $162.568 .811,8$ \\
\hline $\begin{array}{l}\text { Sales_Phase of the COVID-19 } \\
\text { Pandemic }\end{array}$ & 110 & 2.000 .000 & 100.000 .000 & $25.333 .333,3$ & $2.168 .639,4$ \\
\hline $\begin{array}{l}\text { Income_Phase Before the COVID-19 } \\
\text { Pandemic }\end{array}$ & 110 & 13.540 .000 & 1.010 .457 .000 & $215.747 .666,7$ & $162.766 .465,1$ \\
\hline Income_Covid 19 Pandemic Phase & 110 & 5.793 .000 & 154.768 .000 & $51.010 .046,7$ & $15.018 .826,3$ \\
\hline $\begin{array}{l}\text { Operating Profit_Phase Before the } \\
\text { COVID-19 Pandemic }\end{array}$ & 110 & 6.093 .000 & 454.705 .650 & 97.086 .450 & $73.244 .909,2$ \\
\hline $\begin{array}{l}\text { Operating Profit_Covid 19 Pandemic } \\
\text { Phase }\end{array}$ & 110 & 1.737 .900 & 46.430 .400 & 15.303 .014 & $5.005 .647,89$ \\
\hline Valid N (listwise) & 110 & & & & \\
\hline
\end{tabular}

Source: Data processed, 2021 
Table 2. Normality Test Results

\begin{tabular}{|l|l|l|r|r|r|r|}
\hline & \multicolumn{3}{l|}{ Kolmogorov-Smirnov ${ }^{\mathrm{a}}$} & \multicolumn{3}{l|}{ Shapiro-Wilk } \\
\hline & Statistic & \multicolumn{1}{l|}{ Df } & \multicolumn{1}{l|}{ Sig. } & \multicolumn{1}{l|}{ Statistic } & Df & \multicolumn{1}{l|}{ Sig. } \\
\hline Sales_Phase Before the COVID-19 Pandemic & 0,295 & 110 & 0.001 & 0,686 & 110 & 0,000 \\
\hline Sales_Phase of the COVID-19 Pandemic & 0,250 & 110 & 0,012 & 0,774 & 110 & 0,002 \\
\hline Income_Phase Before the COVID-19 Pandemic & 0,291 & 110 & 0,001 & 0,726 & 110 & 0,000 \\
\hline Income_Covid 19 Pandemic Phase & 0,301 & 110 & 0,000 & 0,892 & 110 & 0,000 \\
\hline $\begin{array}{l}\text { Operating Profit_Phase Before the COVID-19 } \\
\text { Pandemic }\end{array}$ & 0,273 & 110 & 0,003 & 0,769 & 110 & 0,000 \\
\hline Operating Profit_Covid 19 Pandemic Phase & 0,298 & 110 & 0,000 & 0,845 & 110 & 0,000 \\
\hline
\end{tabular}

Source: Data processed, 2021

The average value of income decreased when SMMEs in Buleleng Regency experienced the COVID 19 pandemic phase compared to the phase before experiencing the COVID 19 pandemic. The average value of income during the phase before experiencing the COVID 19 pandemic was $215,747,666.7$ while the average value The average income during the COVID19 pandemic phase was 51,010,046.7. The declining average income of 164,737,620 shows that the COVID19 pandemic situation has had a negative impact on the financial condition of SMMEs when viewed from changes in the value of income.

When viewed from another financial aspect, namely changes in operating profit, it was found that there was a decrease in the average operating profit, which means that the COVID-19 pandemic situation has had a negative impact on the financial condition of SMMEs when viewed from changes in the value of operating profits. The average value of operating profit during the phase before the COVID-19 pandemic was 97,086,450, while the average value of operating profit during the phase of the COVID-19 pandemic was $15,303,014$. The decrease in the average value of operating profit from the phase before experiencing the COVID 19 pandemic to the situation during the COVID 19 pandemic phase was $81,783,436$.

The results of the Shapiro-Wilk normality test indicate that the research data is not normally distributed as evidenced by a significance value $<0.05$ for each observation of sales, income and operating income as shown in Table 2. The results of the normality test which show that the research data are not normally distributed cause the data cannot be tested using parametric statistical tests, therefore the test is carried out by non-parametric statistical tests using Wilcoxon signed rank.

\subsection{Data Categorization}

Observational data on sales, revenue, and operating profit in the pre-COVID 19 pandemic phase and in the COVID-19 pandemic condition phase will then be classified into three categories, namely high category, medium category, and low category to determine differences in sales, revenue, and operating profit levels. based on the situation before and after entering the COVID-19 pandemic condition phase. The step taken was to divide the data into three categories using the formula as shown in Table 3 below.

The results of categorization of sales data before the COVID 19 pandemic based on the calculation of the formula in Table 3 are presented in Table 4, while the sales data after entering the COVID-19 pandemic situation based on the calculation of the formula in Table 3 is presented in Table 5.

Table 3. Data Categorization Formula

\begin{tabular}{|l|l|}
\hline Classification & Interval \\
\hline High & $\mathrm{X}>\mathrm{M}+1 \mathrm{SD}$ \\
\hline Medium & $\mathrm{M}-1 \mathrm{SD} \leq \mathrm{X} \leq \mathrm{M}+1 \mathrm{SD}$ \\
\hline Low & $\mathrm{X}<\mathrm{M}-1 \mathrm{SD}$ \\
\hline
\end{tabular}

Source: Statistics (Riwidikdo, 2009)

Table 4. Sales Data Categorization Results Before the COVID-19 Pandemic

\begin{tabular}{|l|l|l|l|}
\hline Category & Score & Total & Percentage \\
\hline \multirow{2}{*}{ High } & $>$ & 15 & $13,64 \%$ \\
\hline \multirow{2}{*}{ Medium } & $\begin{array}{l}28.097 .854 .478,9- \\
353.235 .478,5\end{array}$ & 67 & $60,91 \%$ \\
\hline Low & $<28.097 .854,9$ & 28 & $25,45 \%$ \\
\hline Total & \multicolumn{2}{|l}{110} & $100 \%$ \\
\hline
\end{tabular}

Source: Data processed, 2021 
Table 5. Sales Data Categorization Results After Entering the COVID-19 Pandemic

\begin{tabular}{|c|c|c|c|}
\hline Category & Score & Total & Percentage \\
\hline High & $>$ & 27 & $24,55 \%$ \\
\hline Medium & $\begin{array}{l}23.164 .693,9 \\
- \\
27.501 .972,7\end{array}$ & 9 & $8,18 \%$ \\
\hline Low & $\begin{array}{l}<3.164 .693,9 \\
23\end{array}$ & 74 & $67,27 \%$ \\
\hline Total & & 110 & $100 \%$ \\
\hline
\end{tabular}

Source: Data processed, 2021

Table 6. Income Data Categorization Results Before the COVID-19 Pandemic

\begin{tabular}{|c|c|c|c|}
\hline Category & Score & Total & Percentage \\
\hline High & $>378.514 .131,8$ & 16 & $14,55 \%$ \\
\hline Medium & $\begin{array}{l}52.981 .201,6- \\
378.514 .131,8\end{array}$ & 65 & $59,09 \%$ \\
\hline Low & $<52.981 .201,6$ & 29 & $26,36 \%$ \\
\hline Total & & 110 & $100 \%$ \\
\hline
\end{tabular}

Source: Data processed, 2021

Sales data before the COVID-19 pandemic had a range of $\mathrm{X}>353,235,478.5$ for the high category, $28,097,854.9<X<353,235,478.5$ for the medium category, and $X<28,097,854.9$ for the low category. Based on this categorization, it shows that $13.64 \%$ of the assessments are in the high category, $60.91 \%$ in the medium category, and $25.45 \%$ in the low category. These results show that the sales position of SMMEs in Buleleng Regency before the COVID-19 pandemic was in the medium category. Meanwhile, sales data after entering the COVID-19 pandemic had a range of $\mathrm{X}>$ $27,501,972.7$ for the high category, $23,164,693.9<\mathrm{X}<$ $27,501,972.7$ for the medium category, and $X<$ $23,164,693.9$ for the low category. Based on this categorization, it shows that $24.55 \%$ of UMKM's assessment of sales is in the high category, $8.18 \%$ in the medium category, and $67.27 \%$ in the low category. These results indicate that the sales position of SMMEs in Buleleng Regency after entering the COVID-19 pandemic is in the low category.

The results of the categorization of income data before the COVID 19 pandemic based on the calculation of the formula in Table 3 are presented in Table 6, while the income data after entering the COVID-19 pandemic situation based on the calculation of the formula in Table 3 is presented in Table 7

Income data before the COVID-19 pandemic had a range of $X>378,514,131.8$ for the high category, $52,981,201.6<X<378,514,131.8$ for the medium category, and $X<52,981,201.6$ for the low category. Based on this categorization, it shows that $14.55 \%$ of the assessments are in the high category, $59.09 \%$ in the medium category, and $26.36 \%$ in the low category.
These results show that the income position of SMMEs in Buleleng Regency before the COVID-19 pandemic was in the medium category. Meanwhile, income data after entering the COVID-19 pandemic has a range of $\mathrm{X}$ $>66,028.873$ for the high category, 36,991,220.4 < X < $66,028.873$ for the medium category, and $\mathrm{X}<$ $36,991,220.4$ for the low category. Based on this categorization, it shows that $27.27 \%$ of UMKM's assessment of sales is in the high category, $25.45 \%$ in the medium category, and $47.28 \%$ in the low category. These results show that the income position of SMMEs in Buleleng Regency after entering the COVID-19 pandemic is in the low category.

The results of the categorization of operating profit data before the COVID 19 pandemic based on the calculation of the formula in Table 3 are presented in Table 8, while the operating profit data after entering the COVID-19 pandemic situation based on the calculation of the formula in Table 3 is presented in Table 9.

Table 7. Income Data Categorization Results After Entering the COVID-19 Pandemic

\begin{tabular}{|l|l|l|l|}
\hline Category & Score & Total & Percentage \\
\hline High & $>66.028 .873$ & 30 & $27,27 \%$ \\
\hline Medium & $\begin{array}{l}36.991 .220,4 \\
-66.028 .873\end{array}$ & 28 & $25,45 \%$ \\
\hline Low & $\begin{array}{l}< \\
36.991 .220,4\end{array}$ & 52 & $47,28 \%$ \\
\hline Total & & 110 & $100 \%$ \\
\hline
\end{tabular}

Source: Data processed, 2021

Table 8. Operational Profit Data Categorization Results Before the COVID-19 Pandemic

\begin{tabular}{|l|l|l|l|}
\hline Category & Score & Total & Percentage \\
\hline High & $>170.331 .359,2$ & 14 & $12,73 \%$ \\
\hline Medium & $\begin{array}{l}23.841 .540,8- \\
170.331 .359,2\end{array}$ & 66 & $60 \%$ \\
\hline Low & $<23.841 .540,8$ & 30 & $27,27 \%$ \\
\hline Total & & 110 & $100 \%$ \\
\hline
\end{tabular}

Source: Data processed, 2021

Table 9. Operational Profit Data Categorization Results After Entering the COVID-19 Pandemic

\begin{tabular}{|l|l|l|l|}
\hline Category & Score & Total & Percentage \\
\hline High & $>20.308 .661,89$ & 29 & $26,36 \%$ \\
\hline Medium & $\begin{array}{l}10.297 .366,11- \\
20.308 .661,89\end{array}$ & 29 & $26,36 \%$ \\
\hline Low & $<10.297 .366,11$ & 52 & $47,28 \%$ \\
\hline Total & & 110 & $100 \%$ \\
\hline
\end{tabular}

Source: Data processed, 2021

Operating profit data before the COVID-19 pandemic had a range of $X>170,331,359.2$ for the high category, $23,841,540.8<\mathrm{X}<170,331,359.2$ for the medium category, and $X<23,841,540.8$ for the low category. Based on this categorization, it shows that $12.73 \%$ of the assessments are in the high category, 
$60 \%$ in the medium category, and $27.27 \%$ in the low category. These results show that the position of SMMES operating profit in Buleleng Regency before the COVID-19 pandemic was in the medium category. Meanwhile, operating profit data after entering the COVID-19 pandemic has a range of $X>20,308,661.89$ for the high category, $10,297,366.11<\mathrm{X}<$ 20,308,661.89 for the medium category, and $\mathrm{X}<$ $10,297,366.11$ for the low category. Based on this categorization, it shows that $26.36 \%$ of SMMES's assessment of operating profit is in the high category, $26.36 \%$ in the medium category, and $47.28 \%$ in the low category. These results indicate that the position of SMMES operating profit in Buleleng Regency after entering the COVID-19 pandemic is in the low category.

\subsection{Differences in Sales, Revenue and Operating Profits Between Before and After Entering the COVID-19 Pandemic}

Table 10 shows the results of the Wilcoxon signed rank test with the acquisition of 63 SMMEs in Buleleng Regency experiencing a decrease in sales value and there are 19 SMMEs in Buleleng Regency which actually experienced an increase in sales value during the COVID 19 pandemic as indicated by the negative ranks value at $\mathrm{N}$ value of 63 , and positive ranks at an $\mathrm{N}$ value of 19. Meanwhile, 28 SMMEs in Buleleng Regency have the same sales value before and after entering the COVID-19 pandemic phase as seen from the ties value at an $\mathrm{N}$ value of 28 .

Table 10 also shows that there are 56 SMMEs in Buleleng Regency which experienced a decrease in income during the COVID 19 pandemic which is indicated by the negative ranks value at $\mathrm{N}$ value of 56 . Furthermore, there are 15 SMMEs in Buleleng Regency which experienced an increase in income during the COVID 19 pandemic seen from the positive ranks. at an $\mathrm{N}$ value of 15 and 39 SMEs in Buleleng Regency which have the same income value during the COVID-19 pandemic based on the $\mathrm{N}$ value in ties of 39 .

For the value of operating profit, table 10 shows that the results obtained are that there are 59 SMMEs in Buleleng Regency which have decreased in operating profit and there are 14 companies that have increased in operating profit during the COVID 19 pandemic as indicated by the negative ranks value at an $\mathrm{N}$ value of 59 , and positive ranks of 14 . In addition, the operating profit value has a ties value of 37 which means that there are 37 SMMEs in Buleleng Regency which have the same operating profit value between before COVID 19 and after entering the COVID 19 pandemic phase.

Tabel 10. Wilcoxon Result Signed Rank Test

\begin{tabular}{|c|c|c|c|c|}
\hline & & $\mathrm{N}$ & Mean Rank & Sum of Ranks \\
\hline \multirow{4}{*}{$\begin{array}{l}\text { Sales on COVID } 19 \text { Pandemic-- } \\
\text { Sales Before Entering the COVID- } \\
19 \text { Pandemic }\end{array}$} & Negative Ranks & $63^{a}$ & 35,80 & 2255,4 \\
\hline & Positive Ranks & $19^{\mathrm{b}}$ & 15,57 & 295,83 \\
\hline & Ties & $28^{\mathrm{c}}$ & & \\
\hline & Total & 110 & & \\
\hline \multirow{4}{*}{$\begin{array}{l}\text { Income on COVID } 19 \text { Pandemic- } \\
\text { Income Before Entering the } \\
\text { COVID-19 Pandemic }\end{array}$} & Negative Ranks & $56^{\mathrm{d}}$ & 31,26 & 1750,56 \\
\hline & Positive Ranks & $15^{\mathrm{e}}$ & 14,02 & 210,3 \\
\hline & Ties & $39^{f}$ & & \\
\hline & Total & 110 & & \\
\hline \multirow{4}{*}{$\begin{array}{l}\text { Operational Profit on COVID } 19 \\
\text { Pandemic-Operational Profit } \\
\text { Before Entering the COVID-19 } \\
\text { Pandemic }\end{array}$} & Negative Ranks & $59^{g}$ & 33,44 & 1972,96 \\
\hline & Positive Ranks & $14^{\mathrm{h}}$ & 13,85 & 193,9 \\
\hline & Ties & $37^{\mathrm{i}}$ & & \\
\hline & Total & 110 & & \\
\hline
\end{tabular}

Source: Data processed, 2021 
Tabel 11. Hasil Wilcoxon Signed Rank Test

\begin{tabular}{|l|r|r|r|}
\hline \multicolumn{2}{|c|}{$\begin{array}{c}\text { Sales Before } \\
\text { Entering the COVID- } \\
19 \text { Pandemic }\end{array}$} & $\begin{array}{c}\text { Income Before } \\
\text { Entering the } \\
\text { COVID-19 } \\
\text { Pandemic }\end{array}$ & $\begin{array}{l}\text { Operational } \\
\text { Profit Before } \\
\text { Entering the } \\
\text { COVID-19 } \\
\text { Pandemic }\end{array}$ \\
\hline Z & $-3,048^{\mathrm{b}}$ & $-2,710^{\mathrm{c}}$ & $-2,857^{\mathrm{b}}$ \\
\hline $\begin{array}{l}\text { Asymp. } \\
\text { Sig. (2- } \\
\text { tailed) }\end{array}$ & 0,00 & 0,01 & 0,01 \\
\hline
\end{tabular}

Source: Data processed, 2021

\subsection{The results of the Wilcoxon signed rank test}

The results of the Wilcoxon signed rank test as listed in Table 11 show that there are significant differences in the value of sales, revenue and operating profit between the pre-COVID-19 pandemic phase and the COVID-19 pandemic phase which can be seen from the Asymp value. Sig. (2-tailed) are 0.00 and $0.01<0.05$.

In the sale of obtaining the value of Asymp. Sig. (2tailed) is worth 0.00 which states that there is a difference in terms of sales experienced by SMMES actors between before and after experiencing the economic crisis due to the COVID-19 pandemic, then $\mathrm{H} 1$ is accepted. In Asymp results. Sig. (2-tailed) income is 0.01 which means there is a difference in terms of income experienced by SMMES actors between before and after experiencing the economic crisis due to the COVID-19 pandemic, then H2 is accepted. And based on Asymp. Sig. (2-tailed) operating profit of 0.01 states that there is a difference in terms of operating profit experienced by SMMES actors between before and after experiencing the economic crisis due to the COVID-19 pandemic, then $\mathrm{H} 3$ is accepted.

The economic crisis situation will certainly cause a decline in sales in the industrial sectors due to the declining purchasing power of the people (Wijayaangka, 2014). If the sales of the industrial sector experience a decline during the economic crisis caused by the COVID-19 pandemic, then this will certainly affect the company's financial condition in general, including the value of income. When sales and revenues experience a significant decline, it will certainly affect the company's profits and cash received on cash sales transactions. Revenue from minimal sales will certainly reduce the company's ability to cover all operational costs incurred so that the company will experience losses. During the monetary crisis, net income decreased significantly due to the weakening of people's purchasing power.

In crisis conditions, a decrease in spending interest becomes a natural thing [18]. The decrease in shopping interest has an effect on the value of sales and directly too effect on income [19]. During the pandemic, work operations are limited so it is assumed that it will have an impact on sales, income, and profits. The results showed that operating hours had a positive and significant effect on revenue, sales, and profits [6]; [7]. The research results of reference [20] showed that the COVID-19 pandemic had a significant negative impact on the performance of Chinese companies as a result of a decrease in the value of total revenue. The COVID-19 pandemic has led to the loss of shoppers, as they have to stay at home and households have also tightened spending due to declining incomes. Some SMMEs and small traders can still operate and some choose to close in an undetermined time [21].

\section{REFERENCES}

[1] M. of F. of the R. of Indonesia, OUR APBN (Performance and Facts) Kaleidoscope 2020. Indonesia, 2020.

[2] C. Wijayangka, "Analisis Kinerja Keuangan Perusahaan Sektor Manufaktur Akibat Krisis Keuangan Amerika," J. Manaj. Indones., vol. 14, no. 2, pp. 172-180, 2014, doi: 10.25124/jmi.v14i2.361.

[3] F. M. Bintang, A. Malikah, and Afifudin, "Pengaruh Opini Audit Tahun Sebelumnya, Debt Default, Rasio Likuiditas, Rasio Leverage Terhadap Opini Audit Going Concern," E-JRA Vol. 08 No. 10 Fak. Ekon. dan Bisnis Univ. Islam Malang PENGARUH, vol. 08 , no. 18 , pp. $98-115$, 2019.

[4] W. Hadiwardoyo, "Kerugian Ekonomi Nasional Akibat Pandemi Covid-19," Baskara J. Bus. Enterpreneursh., vol. 2, no. 2, pp. 83-92, 2020, doi: 10.24853/baskara.2.2.83-92.

[5] X. Yongping Sun, Ying Yang, NanHuang, "The impacts of climate change risks on financial performance of mining industry: Evidence from listed companies in China," Resour. Policy, vol. 69, no. 69-80, 2020, doi: https://doi.org/10.1016/j.resourpol.2020.101828.

[6] A. A. N. G. Maheswara, N. D. Setiawina, and I. A. N. Saskara, "Analisis faktor-faktor yang mempengaruhi pendapatan UMKM sektor perdagangan di Kota Denpasar," E-Jurnal Ekon. dan Bisnis Univ. Udayana, vol. 5, no. 12, pp. 4271-4298, 2016.

[7] N. P. R. Sasmitha and A. A. K. Ayuningsasi, "Faktor-faktor yang mempengaruhi pendapatan pengrajin pada industri kerajinan bambu di Desa Belega Kabupaten Gianyar," E-Jurnal EP Unud, vol. 6, no. 1, pp. 64-84, 2017. 
[8] S. Sukirno, Microeconomic Theory Introduction. Third Edition. Jakarta: Raja Grafindo Persada, 2005.

[9] I. B. R. D. Mantra, "Denpasar: Kota Kreatif Berbasis Budaya Unggulan,” Warta Ekspor. 2011.

[10] B. Arifin, Indonesia's Macro-Micro-Economic Formation. Jakarta: INDEF Library, 2002.

[11] Y. Supriadi and R. Puspitasari, "Effect of Working Capital on Sales and Profitability of the Company at PT. Indocement Tunggal Prakarsa Tbk," Unity Sci. J., vol. 14, no. 1, 2012.

[12] S. Yuniartini, "Pengaruh Modal, Tenaga Kerja dan Tekonologi terhadap Produksi Industri Kerajinan Ukiran Kayu di Kecamatan Ubud," E-Jurnal EP Unud, vol. 2, no. 2, pp. 95-101, 2013.

[13] A. H. Manurung, Capital for SME Business. Jakarta: Compass Book. Mantra, IB 2003. General Demographics. Revised Edition. Yogyakarta: Student Library. Marimbo, 2008.

[14] B. Swastha and I. Sukotjo, Pengantar Bisnis. Yogyakarta: Liberti, 2010.

[15] Harahap, Critical Analysis of Financial Statements. Jakarta: PT Raja Grafindo Persada, 2008.

[16] S. Dwimulyani and S. Shirley, "Analisis Pengaruh Pertumbuhan Rasio-Rasio Keuangan, Laba Bersih, Dan Ukuran Perusahaan Terhadap Prediksi Pertumbuhan Laba Usaha Pada Perusahaan Manufaktur Yang Terdaftar Di Bej,” J. Informasi, Perpajakan, Akuntansi, Dan Keuang. Publik, vol. 2, no. 1, p. 43, 2018, doi: 10.25105/jipak.v2i1.4426.

[17] Sugiyono, Metode Penelitian Pendidikan Pendekatan Kuantitatif, kualitatif, dan R\&D. Bandung: Alfabeta, 2018.

[18] S. Devi, N. M. . Warasniasih, and P. R. Masdiantini, "The Impact of COVID-19 Pandemic on the Financial Performance of Firms on the Indonesia Stock Exchange," J. Econ. Business, Account. Ventur., vol. 23, no. 2, 2020.

[19] A. Yoebrilianti, "Pengaruh Promosi Penjualan Terhadap Minat Beli Produk Fashion dengan Gaya Hidup Sebagai Variable Moderator (Survei Konsumen pada Jejaring Sosial)," J. Manaj., vol. 8, no. 1, pp. 20-41, 2018.

[20] H. Shen, M. Fu, H. Pan, Z. Yu, and Y. Chen, "The Impact of the COVID-19 Pandemic on Firm Performance," Emerg. Mark. Financ. Trade, vol. 56, no. 10, pp. 2213-2230, 2020, doi: 10.1080/1540496X.2020.1785863.
[21] dan A. K. Komara, Dwi Beni, Heri Cahyo Bagus Setiawan, "Jalan Terjal UMKM dan Pedagang Kecil Bertahan di Tengah Pandemi Covid-19 dan Ancaman Krisis Ekonomi Global," J. Chem. Inf. Model., vol. 53, no. 9, pp. 1689-1699, 2020. 